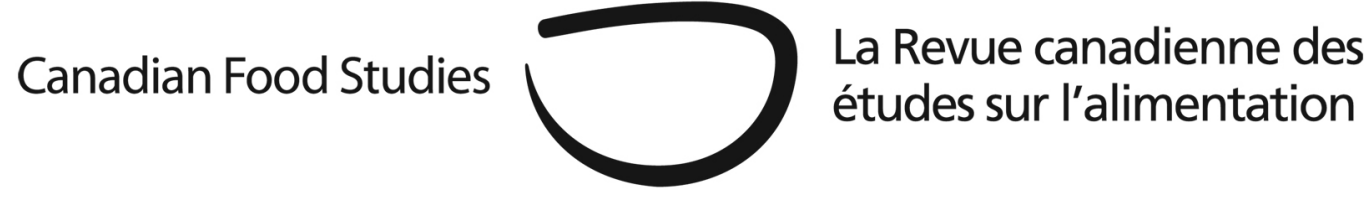

Original Research Article

\title{
The dilemma of scaling up local food initiatives: Is social infrastructure the essential ingredient?
}

\author{
Sean Connelly and Mary Beckie ${ }^{b}$ \\ a Senior Lecturer, Department of Geography, University of Otago, New Zealand \\ sean.connelly@otago.ac.nz \\ ${ }^{\mathrm{b}}$ Associate Professor, Faculty of Extension, University of Alberta, Canada
}

\section{Abstract}

In this paper we examine two responses to the challenge of scaling up local food initiatives (LFIs). Comparative case studies of the City of Edmonton's Good Food Box and the Rimbey farmers' market, both located in central Alberta, are analysed to compare the different strategies used to scale up their impacts and provide a meaningful alternative to the status quo. LFIs offer a variety of context-specific responses and values that aim to challenge the global, conventional food system. In attempting to be viable, many LFIs focus on securing physical infrastructure. Our findings suggest that investment in social infrastructure is crucial for maintaining the values and integrity of LFIs; nevertheless, there are challenges of doing so when competing with the mainstream food system where price, efficiency, and convenience rule. Social infrastructure provides opportunities for a reflexive scaling up by identifying the levers and catalysts for longer-term transformative change. Investments in social infrastructure can support radical and strategic incremental changes by managing associated risks. We conclude that social infrastructure is critical for building support for, and attention to, opportunities to develop connections, networks and partnerships for change within the food system and beyond.

Keywords: local food initiatives; alternative food initiatives, scaling up; social infrastructure; physical infrastructure; reflexive change 


\section{Introduction}

In 1977, Frances Moore Lappé and Joseph Collins suggested that grappling with food issues "provides the most useful tool in making sense out of our complex world (p. 3)." Since that time, concerns about health, the environment, local economies and rural communities have shaped the emergence of a wide range of alternative LFIs. Some take their cue from the 100mile diet or the organic food movement. Others are driven by support for re-localization of economic activity, preservation of farmland, and the family farm. Still others are influenced by peak oil and climate change impacts. There are inspiring and diverse examples of LFIs from around the world that have made significant inroads in raising awareness about where our food comes from, how it is produced, and how waste is addressed. They have influenced markets, generated new business opportunities, and shifted agricultural production from export to satisfying local needs (Marsden \& Smith, 2005). Recent analysis from the United States shows the rapid growth of local food purchasing in the country: a $27 \%$ increase from 2008 (USD $\$ 4.8$ billion) to 2012 (USD \$6.1 billion) (USDA/ARMS ${ }^{1}$ ); a 33\% increase from 2013 (USD \$9 billion) to 2014 (USD \$12 billion) (AT Kearney, 2015); and a predicted 9\% annual growth into 2018 (AT Kearney, 2015).

Similar upward trends are emerging in Canada. The province of Alberta, where the agri-food industry has been dominated by large scale, export-oriented crop and livestock operations, has experienced strong growth in production and processing for local markets as a result of increasing demand (AARD, 2013). In 2012, 93\% of households surveyed purchased food grown or made in Alberta. Increased demand has spawned the growth of local food venues including farmers’ markets, Community Supported Agriculture (CSA) initiatives, box schemes, farm retail, and restaurants. Average household expenditures at farmers' markets doubled from 2004 (CAN \$317) to 2012 (CAN \$617), a period that included a major economic crisis and recession (AARD, 2013). From September 2011 to August 2012 the total economic value of markets across the province was CAN $\$ 724$ million, $90 \%$ more than in 2008 (AARD, 2013).

The fact that LFIs exist, are growing in number and economic value, and are part of broader global food security and food sovereignty movements to reimagine the food system (Larder, Lyons, \& Woolcock, 2014), illustrates the "politics of possibility in the here and now" (Gibson-Graham, 2006; p. xxvi). Yet, despite strong growth in demand for local food and the success of many of these initiatives, their collective economic value is only a small percentage of total food sales. Large retail outlets, such as Walmart ${ }^{2}$, are quickly capitalizing on demand for local food. In Alberta, mainstream retailers now capture $51 \%$ of the local food market (AARD, 2013). Can the impact of diverse, place-based and often small-scale LFIs be strengthened in order to transform rather than merely inform the conventional food system?

Efforts to scale-up LFIs tend to focus on the need for the physical infrastructure (e.g. distribution, storage, retail space, etc.) without sufficient attention to the social infrastructure

\footnotetext{
${ }^{1}$ http://www.ers.usda.gov/media/1763057/ap068.pdf

${ }^{2}$ http://corporate.walmart.com/global-responsibility/environment-sustainability/sustainable-agriculture
} 
(e.g. governance, relationships, networks, values) and the socio-political movements that give rise to these alternatives in the first place (Bloom \& Hinrichs, 2011; Connelly, Markey, \& Roseland, 2011; Friedmann, 2007). Food hubs (Cleveland, Müller, Tranovich, Mazaroli, \& Hinson, 2014) and local procurement policies (Morgan \& Sonnino, 2007; Friedmann, 2007) are examples of strategies used to stimulate the scaling-up of LFIs by increasing demand for local products, create economies of scale, and provide greater access to consumers.

Approaches that "piggyback" on conventional food system infrastructure (such as existing distribution networks, warehousing, storage and processing facilities, etc.) have received significant attention, while alternative ways in which that infrastructure might be used and shared (such as cooperative distribution, shared facilities, consumer-producer partnerships) have been under examined. Bloom \& Hinrichs (2011) found that strategies that relied on conventional food system infrastructure to move food from field to plates struggled to create a sense of partnership as various actors used food system infrastructure for competing purposes. They found that the focus on physical infrastructure was a distraction from developing appropriate governance structures, a sense of shared ownership, equity, and trust among food system participants (Bloom \& Hinrichs, 2011). While utilizing conventional food system infrastructures may be effective in getting more local food to more consumers, it does not provoke examination of the un-sustainable practices of the food system nor thinking about ways that food can aid in the sustainable transformation of communities. The use of infrastructure needs to be linked more explicitly with alternative food system goals (Stevenson \& Pirog, 2008).

The purpose of this paper is to examine and compare two responses to the challenge of scaling up LFIs in Alberta. We conducted comparative case studies of the Good Food Box program in the City of Edmonton and a farmers' market in the Town of Rimbey, both located in central Alberta, to examine the different strategies used to provide a meaningful alternative to the status quo, and the opposing values and objectives that influenced the choice of strategies and the eventual outcomes for each initiative. These examples illustrate the different roles of physical infrastructure and social infrastructure in LFIs, and the tensions that can arise during attempts to scale up their scope and impact. Our findings from these two case studies suggest that investment in social infrastructure is crucial to maintaining the values and integrity of LFIs, and can also result in measured scaling up and lower risk than investing more heavily in physical infrastructure or relying on what is available through the conventional food system. We use these comparative studies to add to previous analysis of the role of social infrastructure in scaling innovations for sustainability (e.g., Beckie, Kennedy, \& Wittman, 2012; Howaldt \& Schwarz, 2010; Kirwan, Ilbery, Maye, \& Carey, 2013; Smith \& Seyfang, 2013). 


\section{Literature review}

\section{LFls and the dilemma of scale}

LFIs can be characterized by their focus on locally controlled, shortened supply chains that attempt to trade on the basis of social, environmental, nutritional, or health qualities, often by re-embedding the economy within social networks (Winter, 2003; Seyfang, 2006; Larder, Lyons, \& Woolcock, 2014). LFIs take many forms. The Stop, in Toronto, serves as a community food centre that supports community gardens, produces food for their food bank and community kitchens, provides meeting space for food democracy and justice movements, and has been a key driver in food policy in Toronto (Levkoe, 2006). Similarly, Growing Power in Milwaukee serves as an urban farm and educational centre that addresses issues of race, inequality, community building, and public health (Allen, 2012). Entrepreneurial approaches, like Small-Plot INtensive (SPIN)-Farming in urban settings, focus on high-value crops marketed directly to consumers to improve the profitability for farmers while integrating agriculture into the built environment (Christensen, 2007). Farmers' markets (e.g., Beckie et al., 2012), community supported agriculture schemes, good food boxes and local food hubs (Beckie \& Connelly, 2016), and urban planning (Mendes, Balmer, Kaethler, \& Rhoads, 2008) provide opportunities for direct interactions between producers and consumers who seek ways to reconnect and "opt-out" of the "disembedded" and globalized food system (Goodman \& Goodman, 2009). The value of LFIs rests not in a replicable, onesize fits all model that can be rolled out across places, but in the differentiated way that individual places respond to the shared challenges and impacts that result from the global, conventional food system. LFIs provide a diversity of context-specific responses and solutions to local challenges created by the conventional food system (Blay-Palmer, Sonnino, \& Custot, 2016)

While there has been an expansion in the number and diversity of LFI approaches, their ability to achieve social, economic, and environmental change is limited by their scale and their position within a broader food system (Jarosz, 2008). In addition, important critiques of LFIs have emerged based on the "local trap" (Born \& Purcell, 2006), the selective participation of privileged sectors of society (Allen \& Guthman, 2006) and the fixation on authenticity, defensive localism and the "othering" of the non-local (Winter, 2003). These critiques have been effective at generating attention, in theory and in practice, to reflexive localisation that openly questions the values and assumptions of specific LFIs (Levkoe, 2011). While many LFIs have arisen out of a broad ideological commitment to sustainability, food security, and social justice, they often struggle to implement this commitment in their daily practices (Connelly, Markey, \& Roseland, 2011). Attempts to transform the food system reveal conflicting tensions, challenges and opportunities as LFIs navigate the difficult terrain of remaining viable alternatives to the conventional food system within their local contexts, while also contributing to a broader social movement that uses food as a platform and a catalyst for social change (Hassanein, 2003; McClintock, 2013). 
How can LFIs remain viable within a system dominated by large-scale global distribution networks? There are significant resources and interests aligned with the agroindustrial model, ranging from global financial markets, foreign investment in agricultural land, and the influence of global trade agreements (Rosin, Stock, \& Campbell, 2012; Clapp, 2013). LFIs struggle to scale-up the appropriate economic, organizational and physical infrastructure so as to be competitive within the larger food system, while still maintaining social and environmental values and goals that the conventional food system undervalues (Cleveland et al., 2014). This dilemma of scale often results in LFIs making trade-offs between increasing their reach and impact, and their commitment to values-based transformation of the food system. They are faced with scaling-up rapidly by mimicking the conventional system and risk becoming appropriated in the process, or methodically assessing their unique assets, commitment and goals as a means of using grassroots innovations to expand their impact (Smith \& Seyfang, 2013).

\section{The role of social infrastructure and social innovation}

Governance structures and the relationships among food system actors can be referred to as social infrastructure, which defines a political and social space where participants can generate and utilize social capital to advance LFI values and objectives. Social infrastructure consists of the interactive aspects of organizations and institutions that allow them to function as a group (Flora \& Flora, 1993). Nauwelaers and Reid (1995) describe the critical role of social infrastructure in regional innovation, referring to the set of economic, political, and institutional relationships occurring in a given geographical area that generates a collective learning process leading to the rapid diffusion of knowledge and best practice. In contrast to physical infrastructure, social infrastructure is intangible and determines how we use physical infrastructure, for what purposes and how control over it is governed (access, user rights, responsibility for provision, etc.). Flora and Flora (1993) identify the institutions, organizations, and groups of people working on common goals that comprise social networks, and the capacity of these networks to innovate, mobilize resources, and link up with outside expertise and resources, as critical assets of social infrastructure.

Previous research in a range of sectors suggests that context-specific social innovation results in changes in practice by re-imagining how actors might interact with each other and with existing structures and institutions to transform the power dynamics of existing systems (Moulaert, Martinelli, Swyngedouw, \& Gonzalez, 2005; Smith \& Seyfang, 2013). Social innovations are new forms of civic engagement, participation, and empowerment that change the direction of social and economic practice by generating new ideas, new interactions, and new activities that meet multiple social goals (Neumeier, 2012). In the context of LFIs, this involves paying equal attention to the function of physical infrastructure and the social innovations that give rise to social networks, governance rules, and political support that provide a purpose for pursuing alternative food system goals. Flora and Bregendahl (2012) illustrate the role that social infrastructure plays in collaborative CSAs, where the interactive nature of collaborative social structures contribute to the enhancement of community capitals (social, political, cultural, economic, financial, built, and natural) by providing for on-going 
relationships between food system actors. The community capitals framework (Flora \& Flora, 2013) emphasizes the need to balance investments across all types of capital and not to assume that investments in one type of capital can off-set disinvestment in others.

The collaborative component of the CSA is an example of the social infrastructure required to enable communication, commitment, trust, and relationships that are necessary to share the risk and benefits of farming for the local market in a way that achieves multiple community benefits. Jarosz (2000) points to the value of understanding the social relations that exist along the food value chain, which are critical for strengthening viability and vibrancy of alternative food initiatives. It is the social relations among actors along the supply chain that enable the exchange of food information and resources that determines how food gets from fields to plates, and the way in which food is valued. Too often, a false divide is created between food production and food consumption, where production is viewed as a technical activity, while consumption is seen as a social activity (Lowe, Phillipson, \& Lee, 2008). As a result, attempts to create an alternative local food system often resort to placing greater attention on the physical infrastructure needed to get food from producers to consumers and fail to recognize the social relations of production and the technical relations of consumption.

It is assumed that local and alternative food systems are more socially embedded and therefore contribute to re-establishing relationships of trust and accountability between food system users (Sonnino, 2013). It is also argued that the social embeddedness of local food systems provides the basis for re-imagining food systems that use new and existing infrastructure in innovative ways and provides greater benefits for local communities (Feenstra, 1997). In this way, the embeddedness of alternative food systems is the basis on which concerns about sustainability can be re-framed, re-read and re-generated (GibsonGraham, 2006). Therefore, local food system advocates need to focus more on the social infrastructure-namely, how to use infrastructure differently, and how to generate resources and capacity on a more collective basis.

Critical to the evolution of new social relationships and structures that support alternative food systems is collective action, with social infrastructure being at the centre of any transformative change to food system practice (Kirwan et al., 2013). Social infrastructure creates the capacity for communities to challenge the mainstream, develop alternatives and take action in creating social and cultural change rather than just economic growth (Seyfang \& Smith, 2007). Capacity refers to the ability of community to make changes by drawing on the resources available to them individually and collectively (Middlemiss \& Parish, 2010).

Having examined the complexity of establishing LFIs and the tensions, conflicts and challenges that arise, we first provide a brief description of the methods used in data collection and analysis, and then turn to two examples of LFIs from Alberta, which we use as the basis to explore the potential for practices in particular places to lead to meaningful change in the food system. Our case studies highlight the conflicts that emerge as a result of competing values and uncertainty of outcomes, and offer insights into how tensions and conflicts can be addressed while continuing to balance pragmatic short term actions with broader goals of food system transformation. 


\section{Methods}

We utilize and compare case studies (Creswell, 2009) of two LFIs that were part of a larger study of social economy initiatives that advance sustainability (Gismondi, Connelly, Beckie, Markey, \& Roseland, 2016), to examine the challenges and tensions associated with scalingup and scaling-out local food projects in particular places. Case studies are, however, bounded by time, location, and focus (Creswell, 2009). The cases selected here were not intended to be representative of the diversity of LFIs that exist, but rather were chosen because they presented interesting examples of local responses to address broader sustainability goals through improving greater consumption and production of local food. Relying on two unique initiatives and the "force of example" provides context-dependent knowledge that allows for themes to emerge from the analysis (Flyvbjerg, 2006).

The case studies and subsequent analysis are based on semi-structured interviews (45-90 minutes) with key local food stakeholders in Edmonton and Rimbey over the period 2008-2015, as well as analysis of secondary sources, including related documents, websites, grant applications and annual reports. In each case, we sought to better understand the challenges, opportunities and tensions that LFI participants faced in their attempts to change the food system. For the Edmonton case, 11 interviews were conducted with Good Food Box organizers and customers, local food activists, local farmers, and members of the City Council in 2010. Subsequent follow-up telephone interviews were conducted in 2012 and 2013 to update information as the project evolved. For Rimbey, 11 interviews were conducted in 2008 with the market manager, vendors, customers, elected officials, and a provincial government employee responsible for overseeing farmers' markets. Follow-up interviews with the market manager were conducted in 2010 and 2015.

In both cases, interviews were both recorded and transcribed or detailed notes were recorded by the interviewer that were subsequently coded using a mixture of inductive and deductive methods. The results from the key informant interviews and secondary sources provide the basis for the case study narratives that follow. The focus on social infrastructure emerged from our qualitative thematic analysis (Cresswell, 2009) as we attempted to come to terms with drawing lessons from these two different LFIs.

\section{Findings}

\section{The Good Food Box, Edmonton}

Plans for the redevelopment of Class 1 agricultural land in the northeast part of Edmonton served as a catalyst for discussion of the role of food in the City (Beckie, Hanson, \& Schrader, 2013). The Greater Edmonton Alliance (GEA), a non-profit coalition of citizens, church groups, farmers, local businesses, and unions galvanized support for preserving one of the last tracts of agricultural land within the City limits to raise awareness of problems with the existing food system and to link food and land use policy for city planners, politicians, 
and the broader public. The broad-based citizen's movement was successful in raising awareness of the value of the agricultural assets of the northeast sector of the City, including the unique micro-climate, soil capabilities and moisture content, and overall productive capacity for contributing to a more sustainable food and agriculture system for Edmonton (City of Edmonton, 2009). The efforts of GEA are credited with motivating widespread public concern for local food systems in the Edmonton region and to the development of the City's food and agriculture strategy in 2012 (Beckie et al., 2013). It was out of this context that the Good Food Box (GFB) emerged to build on the emerging enthusiasm for local food and to link concerns over redevelopment, urban sprawl and local food systems more generally.

Raising awareness of the value of local food for consumers and the community at large was seen as a key component of a strategy for farmland preservation. GEA organizers recognized that increasing the viability and profitability of local farmers would reduce the pressure for redevelopment. However, the conventional food system dominated by supermarkets provided little incentive for collaboration, which limited consumer access and awareness of local food while at the same time limiting distribution opportunities for producers. Outside of the weekly farmers' market, there were few venues for consumers to access to local food. Likewise, local farmers and producers had limited access to provide their products to consumers. While selling at the farmers' market provided direct access to consumers, it also took the farmer off the farm at critical parts of the growing season. In addition, the lack of local food wholesalers made it difficult to access the restaurant industry. Chefs wishing to source local food often had to buy from multiple producers in order to get the volume required, but faced challenges in addressing other parameters such as quality, size, shape, flavour, and consistency. A restaurant owner commented on the importance of relationships, but also their high temporal cost, stating "growers, consumers, institutional buyers, processors and restaurant owners have limited opportunities to interact and as a result personal relationships and connections have been removed in favour of pursuing efficiencies and economies of scale.” Many were unwilling to make this re-investment in time and energy.

Lack of collaboration was highlighted by one local producer who stated "producers need to work together to create a sense of interdependency rather than competition so that the significant costs, risks and benefits of investing in local food infrastructure can be shared." For some producers, trust, reciprocity and collaboration were identified as being critical for re-building the local food system. However, it was also dependent on raising consumer awareness of the true costs of food. One farmer commented on this challenge, stating:

The trade-offs, costs, and benefits between standardized global food systems and flexible localized food systems need to be more apparent to consumers. If consumers really want a more resilient food system, they need to be willing to accept that food is not a standardized product such as toilet paper. It will come in different shapes, sizes and tastes. 
The GFB was set up in 2009 as a social enterprise pilot project with a purpose of increasing the availability of locally produced food for families in the Edmonton area and with the aim of evolving over time into a fully independent cooperative. Existing producers from the farmers' market were contracted to contribute to a weekly food box that customers paid for in advance for the season. The GFB was designed to provide convenient access to affordable fresh produce for consumers, provide fair market value for producers, to expand marketing and distribution opportunities for producers, be accessible to all and to create jobs for inner-city residents. The GFB ran for six continuous weeks of delivery in 2009, and was expanded to the entire growing season in following years.

The project was initially designed for 110 participants; however, when a call for interest was released, over 1,000 people signed up. GFB organizers were unable to cope with this demand due to limitations in delivery trucks, storage and packing space and sufficient local produce. Distribution was curtailed in the first year: 236 bags of fresh produce were delivered per week; 31 were subsidized for clients of the Edmonton Food Bank. Customer surveys at the end of the year indicated that $88 \%$ of the participants were extremely or very satisfied with the quality of the produce and the price. When asked why they participated, $63 \%$ stated support for local farmers as their primary reason, with 53\% stating support for local food security as their secondary reason. The GFB was successful in building on the emerging local food movement in Edmonton that was created by the opposition to land redevelopment and in generating a values-based commitment to local food that saw food as more than just a commodity. However, there were considerable barriers that prevented food activists (both producers and consumers) from acting on their values, primarily related to the infrastructure requirements of getting food from field to plates.

Local food distribution was fragmented and underdeveloped within Edmonton, and the GFB program was seen as one way to build the connection between the farmers and consumers by providing an alternative to the supermarkets while also maintaining a connection to the social and environmental values that gave rise to interest and concern about local food issues in Edmonton. As one GFB customer and volunteer stated:

I think most of the people I know that have joined up with the GFB did it as much for the good food as for the political reasons because they didn't want it to fail. Right now we are hoping to try and reach out to people who maybe aren't that, who just want the convenience and I think you still have to be a little bit convinced that it's good because you don't get to choose your vegetables and choices are made for you.

In order to provide more food to more people in neighbourhoods throughout the City, the GFB focused on increasing physical infrastructure: warehousing space with cold storage and additional delivery trucks. They also focused on increasing consumer choice. In the 2010 and 2011 seasons, they developed a pre-order purchasing website to expose customers to the range of available products and increase shopping convenience. While the GFB was still committed to organic and sustainable production where possible, it was no longer limited to locally sourced products. Instead, it focused support on businesses that operated locally in 
order to access a greater volume and range of products on a year-round basis. As the program scaled-up, it catered to a more upscale, niche consumer market, with prices for products that reflected those demographics. For example, consumers were able to purchase frozen prepared meals, imported seafoods, meats, seasonings, chocolates, breads, and vegetables, in addition to the standard range of fresh produce available through the food box program during the growing season.

The initial grant that subsidized low-income access was not renewed as the GFB shifted from a social enterprise to a local non-profit organization dedicated to supporting independent and local businesses in the Edmonton area. To off-set this change, one percent of total GFB sales were committed for donation to the Mennonite Central Committee. As the focus of the GFB shifted more towards increasing the volume of sales to offset the investments in physical infrastructure, tensions emerged about the commitment of the GFB towards an alternative to the existing food system and the explicit focus of contributing to a broad local food movement was eroded. These tensions resulted in some of the original members of the GFB leaving the program and running their own bulk buying club out of their kitchen because they did not feel that the GFB was paying enough attention to the values and politics of local food.

The GFB ceased operations in $2012^{3}$ as it was not generating enough revenue to justify the expenses. The GFB was unable to match the supermarkets on price and convenience, and the original values-based commitment to an alternative food movement in the City had also been reduced. The demise of the GFB can be explained in part by an attempt to scale-up too quickly to off-set investments in physical infrastructure by capturing the interests of a broader consumer base that may not have had the same commitment to an alternative food system. In doing so, the GFB neglected the social base of values and people that were part of the action to address wider food, agricultural land, and redevelopment issues in the City.

\section{The Rimbey Farmers' Market}

The Town of Rimbey ${ }^{4}$ (population 2,496) is located between Edmonton and Calgary, in Ponoka County (population 50,000) in central Alberta. The County has well established agricultural and oil and gas industries that support the largely rural-based economy. The agricultural industry is predominantly characterized by large-scale crop and livestock operations but production of vegetables and fruits is on the rise, as is the direct marketing of fresh produce through seasonally operated farmers' markets. There are currently 12 farmers' markets concentrated in this region. Similar to other regions of Alberta and the rest of Canada, these farmers' markets are structured and run mainly as non-profit organizations.

\footnotetext{
${ }^{3}$ One of the growers that originally supplied the GFB has since started up the Organic Box as an independently owned and operated part of their farm. It supplies 2000 boxes of vegetables a week to customers in Edmonton and the surrounding region.

${ }^{4}$ Town of Rimbey: http://www.rimbey.com
} 
Rimbey is within close proximity to three large lakes (Pigeon Lake, Gull Lake, and Sylvan Lake) and provides most services to the surrounding farming population of approximately 12,000. During the summer months, thousands of visitors are drawn to these lakes and other recreational amenities of the region. This influx and the region's rich resource base significantly shape the local economy and creates employment and income opportunities. Unlike many agricultural communities in the prairie region that are declining due to out-migration, the communities within this region have remained relatively stable and economically viable. Strong local economies can be an important factor in the development of viable farmers' markets, however this is not always a given. As will be discussed below, the success of farmers' markets ultimately depends on local leadership and the embeddedness of the market in the community and the region.

Rimbey farmers' market was established in the late 1980s but by 2006 was on the verge of shutting down, with only seven vendors remaining. According to Rimbey market vendors, customers, and a Town Council representative interviewed, a number of factors influenced the decline of the market including: lack of leadership, vision and direction, a poor location, fading interest and support from the Town, and a reputation as having a poor selection of products in comparison to a number of other highly successful markets in the region. In 2007, the market experienced a revival with a new market manager, board of directors, and 42 new vendors. Within one year, the Rimbey market had become "a great reason to get up on Saturday mornings"—a rally call that has become the market's slogan. Since this time, the market has won awards from the Alberta Farmers' Market Association for its community atmosphere and the manager's leadership and innovation. The market manager explained that the market started to become successful once it began to contribute more to the social aspects of the community and transitioned away from a for-profit model that it was previously operating under. Her premise for this was that a locally embedded market can generate a unique community atmosphere that draws people in, and is not typically offered in the conventional food retail sector:

I wanted to make the market a community event where people wanted to go on a Saturday morning, where they wanted to do their shopping, where they wanted to go meet for coffee, meet their friends. If you can make the market a really fun place to be, which is something that is lacking in our society.....Well, I think this is why farmers' markets are so important. We have people coming to the market and dancing. We have older senior couples actually ballroom dancing at the market. All this stuff gives a real sense of community.

A number of different initiatives have aided in bringing community spirit to the Rimbey market: hiring a small bus to pick up seniors; having a volunteer band play each market day; providing family-directed entertainment; supplying a free table for community organizations; and garnering support from local businesses through donations (such as doughnuts and coffee). Rather than being in competition with local businesses, retail managers have found the market to be a way to draw people into the Town, who often continue their shopping after the market. The market is also viewed as an opportune entry 
point for expanding and diversifying production in the area and increasing access to local foods for residents, as evidenced by some of the vendors now supplying the seniors' lodge with fresh vegetables. There has been a desire to make this an environmentally-friendly market, so customers are encouraged to bring their own shopping bags and coffee cups. Every fourth Saturday is an "environmental solutions day", which focuses on local best practices and 'green' inventions, and an effort is made to get children and youth involved.

Through a relationship formed with the Rimbey Historical Society, the market is located on their attractive grounds and has access to buildings and infrastructure at a reasonable cost. The market manager has also worked to develop good working relationships with other markets clustered in central Alberta (Beckie et al., 2012). The region has a group of experienced managers that network with one another, sharing tips on promotion, market development, and potential new vendors, and are investigating ways to share costs and resources for a joint promotional campaign. Market managers in the region also collaborate to arrange market days and hours in order to avoid competition and overlap. This coordination enables the development of a 'market circuit', where it is possible for customers and vendors to attend multiple markets during the week. For example, Innisfail Growers, based in this region, is a partnership of five family farms that sell fresh vegetables at 13 different markets in central, northern, and southern Alberta, on every day of the week except for Monday.

The Rimbey market thus provides a good example of the benefits of investing in social infrastructure for the scaling-up of alternative food initiatives. The commitment to building relationships between community partners, responding to local needs and values, and creating an atmosphere that is unique and cannot be replicated by the conventional food system have all contributed to the success of this farmers' market. The regional clustering of farmers' markets also provides a valuable mechanism for scaling-up and scaling-out the social and environmental benefits, without having to make a major investment in physical infrastructure, such as would be required for the development of a regional food hub.

\section{Discussion}

The cases examined above describe two different LFIs that have contributed to the local food movement in Alberta by utilizing divergent approaches to influence the scaling up of their impacts and the trajectory of change. In this section, we analyze and compare the case studies with reference to the concepts of risk, scale, and infrastructure.

\section{Sharing risk}

Flora \& Flora (1993) stress the importance of social infrastructure in managing risk in any attempt to transform actions. Who should bear the risk? Is it shared equitably among stakeholders? Should it be shared equitably? A process for determining what is an acceptable level of risk and who shares that risk is a critical component of social 
infrastructure. The ability of stakeholders to manage that risk collectively is equally important. The loss of limited resources (both monetary, volunteers, and reputation) is a real threat and can pose a significant barrier to shifting practice from the status quo for consumers and producers alike. However, treating investments in physical or social infrastructure as a zero-sum game fails to acknowledge the interdependencies among the various forms of community capitals (Flora \& Flora, 2013). Likewise, Roseland (2012) emphasizes the important role community mobilization plays in engaging stakeholders to strengthen all types of community capital. Social infrastructure is critical for balancing different types of capital and mobilizing stakeholders to engage in the risks associated with altering the status quo.

The challenge of coping with risk was particularly evident in the GFB case where one farmer discussed the dilemma of scaling up his production to supply additional food for the GFB program:

I want to increase production, but is there really a guaranteed demand for my products? There are considerable risks and challenges associated with investing in scaling up local production, and I don't think those risks can be placed entirely on the back of producers. It's sort of like the chicken and egg question, farmers won't increase supply until they are certain demand exists, but it is hard to raise awareness for consumers if there isn't sufficient supply.

The GFB organizers recognized that what they were trying to do created uncertainties and risks for producers. They attempted to reduce this risk by focusing on investments in physical food system infrastructure (additional depots, cold storage facilities, warehouse, and delivery trucks) to increase access to local food through the GFB. These physical infrastructure investments were designed to expand beyond the niche foodie market by providing drop-off and home delivery options in suburban neighbourhoods and to increase the product range so that consumers had increased choice in a variety of products and readymade meals. However, in the effort to scale-up the impact of the GFB, the focus on convenience for consumers had unintended consequences of alienating some of the supporters of an alternative food system for Edmonton. It also did little to shift the way both producers and consumers interacted. For example, a farmer highlighted the need to:

...develop strategic collaborations among producers to share and address those risks. Producers need to begin to work together, to create interdependency rather than independence, for example, with cooperation around a shared warehouse. We also need to find a way to deal with consumer awareness regarding the challenges of supply. It's hard to work together, but that is what pays. We need to recognize that it is risky and hard. 
Equally, consumers have a role to play. As one original supporter stated, "There is a lot of risk in marketing to where the consumer is at. If it is too easy, is it really a different kind of food system [we are creating]?”

The shift to online ordering and prepared meals undermined the focus on developing relationships between food system participants and building shared values about what a different kind of food system might look like in Edmonton. For some customers, supporting local producers, local businesses, and restaurants was of high priority. However, with the changes, other customers felt that GFB was no longer engaged with challenging producers and consumers to change the way they think about food or how they related to each other. They asked: How was the GFB different from the conventional food system, albeit on a much smaller scale, if the relationships between consumers and producers were limited to an online transaction? The commitment to a values-based approach to food and engagement with the politics of food was in question. Weakening social infrastructure linkages only elevated tensions between opposing views, which were never resolved. In the end, the relationships, networks, and linkages that were built through the coalition formed to fight for agricultural land preservation in the City, which led to the development of the GFB, were insufficient to accommodate the sharing of risk between producers and consumers for this initiative. Most of the risk burden was transferred to the GFB and when they were unable to generate sufficient sales, they ceased operation. However, they did open up a space for discussion of what kinds of LFIs are possible in Edmonton, and should be acknowledged for their contribution to the burgeoning local food movement in the City.

In contrast to the GFB, the Rimbey market has taken the position that "bigger is not always better" and focuses instead on community needs and values, which has aided its success and reduced the financial risk associated with expansion and investment in physical infrastructure. In fact, the manager spoke of limiting the number of vendors at the market so as to "keep its community atmosphere", and avoid the hectic frenzy of some of the larger, tourist-oriented markets. Unlike these markets, Rimbey’s market has a predominantly local customer base which shapes what vendors sell and what social and educational activities are included. Building relationships with local community organizations and Town administration has also embedded the market in the community, such as its partnership with and location on the Rimbey Historical Society's grounds. By strengthening relationships with other market managers in the region, thereby contributing to an integrated and collaborative market circuit, they have also reduced the risk associated with a more competitive approach. The entire supply chain is strengthened when vendors and customers are given more market options, and when vendors can expand production to meet greater demand and can also enter into new market relations.

\section{Scaling-up or scaling-out}

Social infrastructure plays a critical role in addressing the dilemma of scale. Flora and Flora (1993) highlight the importance of vertical and horizontal linkages to provide a diverse source of knowledge and resources. In central Alberta, participation in the cluster of regional markets enables individual markets, managers, and vendors to create a collective competitive 
advantage through expanded horizontal and vertical linkages, which enhance opportunities for collaboration, knowledge, and resource sharing (Beckie et al., 2012). Horizontal collaborations take place among vendors, market managers, and customers and help to shape the "business practices and enterprise development of vendors, in a relatively low-risk environment, by encouraging social learning and innovation” (Hinrichs, Gillespie, \& Feenstra, 2004, p. 32). Vertical relationships with private, public, and social economy sectors extend the network both within and external to the community, and bring in outside resources. Strengthening social relations, trust, and collaboration, both horizontally and vertically, can give rise to social innovations that can aid in "addressing the challenges of scale, scope, infrastructure, and organizational capacity common in alternative food networks” (Beckie et al., 2012, p. 334). By placing greater emphasis on building its social infrastructure, the Rimbey market has adopted a strategy for scaling up that has not eroded its authenticity or detracted from the overarching objective of contributing to a more sustainable and socially just food system (cf. Wittman, Beckie, \& Hergescheimer, 2012; Bloom \& Hinrichs 2011; Friedmann 2007).

Through their efforts to scale up the impact of the GFB by enrolling more participants, there were insufficient resources (time, capacity, money) to adequately engage with how the GFB was going to be scaled out and to discuss the implications. For many, the focus on scaling up represented a failure to address the politics of food and a watering down of the values of equity and environmental responsibility. Initially, food activism in Edmonton was explicitly political and took advantage of horizontal linkages; as one City councillor described:

It is not just about preserving land, but also about community gardens, about health, about making social connections, about the culture and the way we think about food in our daily lives. It really is a food system approach that has appeal across the diverse urban geography of Edmonton, appealing across the spectrum of citizens.

Similar to Flora and Bregendahl's (2012) findings on collaborative CSAs, the quote above illustrates the critical role that collective community capitals produced by participants played in creating a more local, sustainable, and just food system in Edmonton. As the GFB project focused more on scaling-up rather than scaling-out, some of the horizontal linkages that supported multiple community capitals were lost. Constraints on funding and the requirement to generate a growth in consumer numbers and sales to offset investments in the physical food system infrastructure resulted in limited commitment and capacity to draw on these social infrastructure investments that relied in particular on the interconnections between natural, social, political, and cultural capital. 


\section{Conclusion}

The case studies discussed above illustrate the critical importance of paying attention to the social infrastructure of LFIs and also the challenge of doing so while in competition with the mainstream food system where price, efficiency, and convenience rule. Social infrastructure provides opportunities to navigate from short term and pragmatic to long term and transformational objectives. While neither of these cases exemplifies food system transformation, they do provide insights about the challenges, tensions, contradictions, and complexity of transitioning towards sustainability. They highlight the important role that social infrastructure plays in providing opportunities for LFI proponents to be reflective about their practice.

Efforts to scale up can result in being too radical and too risky. Often, the safer bet is to move towards the "low-hanging fruit" and a more incremental approach. Yet as Delind (2011) warns, this approach risks taking attention away from the values and goals of equity, citizenship, place-making, and sustainability that drive many LFI stakeholders and can actually be used to support the status quo. Social infrastructure investments are needed to support radical and strategic incremental changes that can serve as levers and catalysts for broader change. These investments can only be identified by developing and maintaining the horizontal and vertical linkages to manage and balance the risks of building an alternative to the status quo.

Social infrastructure is equally important in maintaining a focus on the "politics of reflexive localization” (Levkoe, 2011, p. 688). The case studies discussed here highlight that social infrastructure is critical to assess what is being scaled-up and why. A reflexive approach to scaling-up ensures that LFIs are not making investments in food system infrastructure simply for the sake of scaling-up and that questions about how the food system operates and how benefits and costs are distributed are addressed. In the context of food system transformation, LFIs require an orientation towards social and environmental justice that will be challenging and risky to implement. Social infrastructure investments are critical for building support and paying attention to opportunities to scale out, which is equally as important as scaling up.

The cases discussed here can be viewed as alternatives to the mainstream food system at present. As Gibson-Graham (2006) discuss, the fact that they exist offer hope that change is possible. The development of horizontal linkages between LFIs embedded in particular places and other social movements committed to social and environmental justice offer opportunities to build collective social infrastructure, which can "potentially realign production-consumption chains and capture local and regional ecological and economic value both within and between rural and urban spaces” (Marsden, 2010, p. 227). Investments in social infrastructure provide the basis for dealing with the complex and messy process of change by focusing not just on the immediate short-term solutions, but on the process of empowering citizens for the long term (Flora \& Flora, 1993). Reframing the risks associated with scaling up their impacts can generate innovative solutions to breaking down boundaries around what is possible. Social infrastructure for LFIs can enable what Gibson-Graham 
(2006) suggest is required to reframe problems, reread already existing solutions, and to creatively generate new possibilities where they did not exist before.

\section{References}

Allen, W. (2012). Good Food Revolution: Growing healthy food, people and communities. Gotham Books: New York.

Allen, P., \& Guthman, J. (2006). From “old school” to "farm-to-school”: Neoliberalization from the ground up. Agriculture and Human Values, 23(4), 401-415.

Alberta Agriculture and Rural Development (AARD). (2013). Alternative agricultural markets in Alberta: A report of the Local Market Expansion Project. Retrieved from: http://www1.agric.gov.ab.ca/\$department/deptdocs.nsf/all/explore14403/\$file/Report AlternativeAgMarkets2012FINAL.pdf?OpenElement

ATKearney, (2015). Firmly Rooted, the Local Food Market Expands. Retrieved from: https://www.atkearney.com/documents/10192/6773369/Firmly+Rooted+the+Local+F ood+Market+Expands.pdf/863737a6-0b44-40d0-b339-da25c4563dc3

Beckie, M., \& Connelly, S. (2016). "The Role of the Social Economy in Scaling Up Alternative Food Systems.” In M. Gismondi, S. Connelly, M. Beckie, S. Markey \& M. Roseland (Eds), Scaling Up: Convergence of the social economy and sustainable community development (pp. 59-81). Athabasca University Press: Edmonton.

Beckie, M., Hanson, L., \& Schrader, D. (2013). Farms or Freeways? Citizen Engagement and Municipal Governance in Edmonton’s Food and Agriculture Strategy Development. Journal of Agriculture, Food Systems and Community Development, 4(1), $15-31$.

Beckie, M., Kennedy, E. H., \& Wittman, H. (2012). Scaling Up Alternative Food Networks: Farmers' Markets and the Role of Clustering in Western Canada. Agriculture and Human Values, 29(3), 333-345.

Blay-Palmer, A., Sonnino, R., \& Custot, J. (2016). A food politics of the possible? Growing sustainable food systems through networks of knowledge. Agriculture and Human Values, 33(1), 27-43.

Bloom, J. D., \& Hinrichs, C. C. (2011). Moving local food through conventional food system infrastructure: Value chain framework comparisons and insights. Renewable Agriculture and Food Systems, 26(01), 13-23. 
Born, B., \& Purcell, M. (2006). Avoiding the local trap scale and food systems in planning research. Journal of Planning Education and Research, 26(2), 195-207.

Christensen, R. (2007). SPIN Farming: Improving revenues on sub-acre plots. Urban Agriculture Magazine, December 2007, 25-26. http://www.ruaf.org/sites/default/files/UAmagazine\%2019\%20H9.pdf

City of Edmonton (2009). The Way Ahead: The City of Edmonton Strategic Plan 2009-2018. http://www.edmonton.ca/city_government/city_vision_and_strategic_plan/the-wayahead.aspx

Cleveland, D. A., Müller, N. M., Tranovich, A. C., Mazaroli, D. N., \& Hinson, K. (2014). Local food hubs for alternative food systems: A case study from Santa Barbara County, California. Journal of Rural Studies, 35, 26-36.

Clapp, J. (2001). Food. Cambridge: Polity.

Creswell, J. W. (2009). Research design: Qualitative, quantitative, and mixed method approaches (3rd ed.). Thousand Oaks, CA: Sage.

Connelly, S., Markey S., \& Roseland, M. (2011). "Bridging Sustainability and the Social Economy: Achieving Community Transformation through Local Food Initiatives.” Critical Social Policy, 31(2), 308-324.

DeLind, L. (2011). Are local food and the local food movement taking us where we want to go? Or are we hitching our wagons to the wrong stars? Agriculture and Human Values, 28(2), 273-283.

Feenstra, G. W. (1997). Local food systems and sustainable communities. American Journal of Alternative Agriculture, 12(1), 28-36.

Flora, C. B., \& Bregendahl, C. (2012). Collaborative community-supported agriculture: balancing community capitals for producers and consumers. International Journal of Sociology of Agriculture and Food, 19(3), 329-346.

Flora, C. B., \& Flora, J. L. (1993). Entrepreneurial Social Infrastructure: A necessary ingredient. Annals of the American Academy of Political and Social Science, 529, 4858.

Flora, C. B., \& Flora, J. L. (2013). Rural Communities: Legacy and Change (4 ${ }^{\text {th }}$ Ed.). Boulder: Westview Press. 
Flyvbjerg, B. (2006). Making social science matter: Why social inquiry fails and how it can succeed again. Cambridge: Cambridge University Press.

Friedmann, H. (2007). Scaling up: Bringing public institutions and food service corporations into the project for a local, sustainable food system in Ontario. Agriculture and Human Values, 24(3), 389-398.

Gibson-Graham, J. K. (2006). A Post-capitalist Politics. Minneapolis: University of Minnesota Press.

Gismondi, M., Connelly, S., Beckie, M., Markey, S., \& Roseland, M. (eds.). (2016). Scaling Up: Convergence of the social economy and sustainability. Edmonton: Athabasca University Press.

Goodman, D., \& Goodman, M. K. (2009). Alternative Food Networks. In R. Kitchin \& N. Thrift (Eds.), International Encyclopedia of Human Geography (pp.208-220). Elsevier: Oxford.

Hassanein, N. (2003). Practicing food democracy: a pragmatic politics of transformation. Journal of Rural Studies, 19(1), 77-86.

Hinrichs, C.C.,Gillespie, G., \& Feenstra, G. (2004). Social learning and innovation at retail farmers’ markets. Rural Sociology, 69(1), 31-55.

Howaldt, J., \& Schwarz M. (2010). Social innovation: concepts, research fields and international trends. Available online at http://www.sfs.tudortmund.de/odb/Repository/Publication/Doc/1289/IMO_Trendstudie_Howaldt_Sch warz_englische_Version.pdf

Jarosz, L. (2000). Understanding agri-food networks as social relations. Agriculture and Human Values, 17(3), 279-283.

Jarosz, L. (2008). The city in the country: Growing alternative food networks in Metropolitan areas. Journal of Rural Studies, 24(3), 231-244.

Kirwan, J., Ilbery, B., Maye, D., \& Carey, J. (2013). Grassroots social innovations and food localisation: An investigation of the Local Food programme in England. Global Environmental Change, 23(5), 830-837.

Larder, N., Lyons, K., \& Woolcock, J. (2014). Enacting Food Sovereignty: Values and meanings in the act of domestic food production in urban Australia. Local Environment, 19 (1), 56-76. 
Levkoe, C. Z. (2006). Learning democracy through food justice movements. Agriculture and Human Values, 23(1), 89-98.

Levkoe, C. Z. (2011). Towards a transformative food politics. Local Environment, 16(7), 687-705.

Lowe, P., Phillipson, J., \& Lee, R. P. (2008). Socio-technical innovation for sustainable food chains: roles for social science. Trends in Food Science \& Technology, 19(5), 226-233.

McClintock, N. (2013). Radical, reformist, and garden-variety neoliberal: coming to terms with urban agriculture's contradictions. Local Environment, 19(2): 147-171.

Marsden, T., \& Smith, E. (2005). Ecological entrepreneurship: sustainable development in local communities through quality food production and local branding. Geoforum, 36(4), 440-451.

Marsden, T. (2010). Mobilizing the regional eco-economy: evolving webs of agri-food and rural development in the UK. Cambridge Journal of Regions, Economy and Society, 3(2), 225-244.

Mendes, W., Balmer, K., Kaethler, T., \& Rhoads, A. (2008). Using land inventories to plan for urban agriculture: Experiences from Portland and Vancouver. Journal of the American Planning Association, 74(4), 435-449.

Middlemiss, L., \& Parrish, B. D. (2010). Building capacity for low-carbon communities: The role of grassroots initiatives. Energy Policy, 38(12), 7559-7566.

Moore Lappe, F., Collins, J., \& Fowler, C. (1977). Food First: Beyond the myth of scarcity. Boston: Houghton Mifflin.

Morgan, K., \& Sonnino, R. (2007). Empowering consumers: the creative procurement of school meals in Italy and the UK. International Journal of Consumer Studies, 31(1), 19-25.

Moulaert, F., Martinelli, F., Swyngedouw, E., \& Gonzalez, S. (2005). Towards alternative model(s) of local innovation. Urban studies, 42(11), 1969-1990.

Nauwelaers, C., \& Reid, A. (1995). Methodologies for the evaluation of regional innovation potential. Scientometrics, 34(3), 497-511.

Neumeier, S. (2012). Why do Social Innovations in Rural Development Matter and Should They Be Considered More Seriously in Rural Development Research? - Proposal for a Stronger Focus on Social Innovations in Rural Development Research. Sociologia Ruralis, 52(1), 48-69. 
Roseland, M. (2012). Towards Sustainable Communities: Solutions for citizens and their governments ( $4^{\text {th }}$ Ed.). Gabriola Island: New Society.

Rosin, C., Stock, P., \& Campbell, H. (Eds.) (2012). Food Systems Failure: The Global Food Crisis and the Future of Agriculture. London: Earthscan Press.

Seyfang, G. (2006). Ecological citizenship and sustainable consumption: Examining local organic food networks. Journal of Rural Studies, 22(4), 383-395.

Seyfang, G., \& Smith, A. (2007). Grassroots innovations for sustainable development: Towards a new research and policy agenda. Environmental Politics, 16(4), 584-603.

Smith, A., \& G. Seyfang (2013). Constructing grassroots innovations for sustainability. Global Environmental Change, 23(5), 827-829.

Sonnino, R. (2013). Local foodscapes: place and power in the agri-food system. Acta Agriculturae Scandinavica B, 63(1), 2-7.

Stevenson, G. W., \& Pirog, R. (2008). Values-based supply chains: Strategies for agrifood enterprises of the middle. In T. A. Lyson, G. W. Stevenson, \& R. Welsh (Eds.), Food and the mid-level farm: Renewing an agriculture of the middle (pp. 119-143). Cambridge: MIT Press.

Winter, M. (2003). "Embeddedness, the new food economy and defensive localism." Journal of Rural Studies, 19(1), 23-32.

Wittman, H., Beckie, M., \& Hergesheimer, C. (2012). Linking Local Food Systems and the Social Economy? Future Roles for Farmers’ Markets in Alberta and British Columbia. Journal of Rural Sociology, 77(1), 36-61. 